\title{
Mirosław Tyl
}

\section{Badania recepcji a problem tradycji w historii filozofii}

\author{
DOI: http://dx.doi.org/10.12775/LC.2017.070
}

dpowiedź na pytanie, jak recepcja ukazuje filozoficzną tradycję, mieści się na styku historii filozofii i filozofii. Chodzi zarówno o rezultat odpowiednio zorientowanych badań historycznych, zarówno o formę filozofowania, które odbywa się w dialogu z przeszłością ${ }^{1}$, jak i o szersze, pozaprofesjonalne internalizowanie idei filozoficznych. W grę wchodzi tu oczywiście nie stwierdzanie prostych związków przyczynowo-skutkowych, ale sens, jaki można im nadać.

Jako przedmiot badań historycznofilozoficznych recepcja wydaje się mało atrakcyjna. Badacze, którzy postanowili się nią zająć, odczuwają na ogół potrzebę usprawiedliwienia się ze swoich wyborów w ramach teoretycznych wstępów lub uwag, w których nieodmiennie powraca temat pożytków płynących z tego typu przedsięwzięć. Przychodzi im bowiem interesować się zjawiskami nieraz drugorzędnymi lub wręcz marginalnymi. Okazuje się jednak - uświadamia to na przykład praktyka badawcza Stefana Swieżawskiego, Barbary Skargi czy Stanisława Borzyma - że drugorzędni autorzy potrafią być ciekawi i na swój sposób ważni, gdyż w ich myśli dochodzą nieraz do głosu autentyczne dylematy oraz specyficzne rysy epoki, w której żyją.

Doświadczenia polskich badaczy recepcji skłaniają do wniosku, że niezależnie od rozmaicie definiowanych celów ten typ badań charakteryzuje swoisty realizm, wyrażający się w bliskim kontakcie z rzeczywistością historyczną; Borzym pisał, że „badanie recepcji ukazuje rzeczywiste, niewyidealizowane życie pewnej koncepcji w dziejach, dialog odbiorców $\mathrm{z}$ wirtualnie istniejącym sensem pierwowzoru"2. Minimalizuje on niebezpieczeństwo konstruktywizmu, któremu łatwiej ulegają inne typy badań historycznych, co skutkuje niejednokrotnie rewizją zastanych stereotypów interpretacyjnych, demaskowaniem historyczno-

\footnotetext{
Dr hab., adiunkt w Zakładzie Filozofii w Polsce na Uniwersytecie Śląskim w Katowicach. E-mail: miroslaw.tyl@us.edu.pl.

1 Filozofia. Podstawowe pytania, red. H. Schnädelbach, E. Martens, tłum. K. Krzemieniowa, Warszawa 1995, s. 36.

2 S. Borzym, Bergson a przemiany światopoglądowe w Polsce, Wrocław-Warszawa 1984, s. 18.
} 
-filozoficznych hipostaz, nade wszystko zaś ukazaniem aspektowej - pars pro toto - ciągłości rzeczywistości historyczno-filozoficznej.

Łatwo zauważyć, że polscy badacze nie pozostali obojętni na osobliwości recepcji i wynikające z nich problemy warsztatowe. Otóż w toku rozwoju refleksji teoretycznej w tym zakresie szczególne miejsce przypisać trzeba referatowi Jana Garewicza: Kilka uwag o badaniu recepcji filozofii, wygłoszonemu na Ogólnopolskim Zjeździe Filozoficznym w 1977 roku. Garewicz, komentując w nim wypowiedzi Władysława Tatarkiewicza i Romana Ingardena ${ }^{3}$, doszedł do wniosku, że choć trzeba uznać recepcję za istotny czynnik tradycji filozoficznej (czynnik dziejotwórczy i w konsekwencji zasługujący ze wszech miar na uwagę badaczy), nie wykorzystuje się tkwiących w niej możliwości badawczych. Brak bowiem odpowiedniego zaplecza dla tego typu badań. Brak teorii recepcji. Ba, sam termin recepcja nie jest - jego zdaniem - na gruncie teorii i metodologii historii filozofii precyzyjnie opracowaną kategorią badawczą: nie ma jasności co termin ten w istocie oznacza i jakie są granice jego stosowalności, brak wreszcie fenomenologicznego opisu odpowiadającego mu zjawiska.

Referat Garewicza zdawał relację z realiów teoretyczno-badawczych lat siedemdziesiątych minionego stulecia. Dziś znajdujemy się w lepszej sytuacji. Od publikacji Granic historyczności Barbary Skargi (1989) dysponujemy teoretycznym układem odniesienia dla analiz przynajmniej niektórych przejawów recepcji - jeśli tylko odpowiednio dostosować koncepcję formacji intelektualnych do tego typu badań. Skarga rozważała na przykład szczegółowo naturę recepcji problemów, podnosząc przy tym niezwykle ważną kwestię ich historycznej tożsamości jako warunku uprawiania historiografii problemów, rozważała zagadnienia trwałości i zmienności kategorii filozoficznych oraz płynności reguł sensu, które organizują pracę myśli.

Otóż wszystko to zachęca do ponowienia refleksji nad możliwościami i znaczeniem badań recepcji w kontekście wskazanego w tytule problemu. W jakim mianowicie sensie studium recepcji i oddziaływania - „drugiego życia” książek, idei, poglądów, problemów, kategorii, pojęć i tym podobnych struktur znaczących - może ukazać tradycję filozofii (jej ciągłość, może jedność), a zatem i genealogię filozoficznej współczesności?

Znaczenie tego pytania łatwo uzasadnić potrzebą samookreślenia się filozofa. Wpisuje się on zazwyczaj (jest to niemal truizm), mniej lub bardziej otwarcie, w historię swej dyscypliny. Postawa taka wypływa z konserwatywnego odruchu: chcemy iść własną drogą, ale mamy świadomość, że aktualizujemy kwestie istotne wcześniej, a jeśli stawiamy nowe pytania, to i tak towarzyszy nam przekonanie, że nie filozofujemy ab ovo i genetycznie osa-

3 J. Garewicz, Kilka uwag o badaniu recepcji filozofii, [w:] Wybrane zagadnienie z historii filozofii polskiej na tle filozoficznej umysłowości europejskiej, red. J. Legowicz, Wrocław 1979, s. 103. Garewicz cytuje i komentuje następujące wypowiedzi, które dobrze przywołać, by zdać sobie sprawę z punktu wyjścia dyskusji oraz zarysowujących się początkowo rozwiązań: 1) W. Tatarkiewicza: „historia filozofii jest po części historią powstawania poglądów filozoficznych, a po części historią ich recepcji. Można je wyodrębnić i oddzielnie traktować sprawy powstawania twierdzeń filozoficznych (dzięki jednostkom ludzkim), a oddzielnie ich recepcji (wśród ogółu). Za oddzieleniem tych części przemawia postulat czystej roboty. Ale postulat roboty kompletnej przemawia przeciw niemu, bo żadna z części nie daje sama obrazu rzeczywistego rozwoju filozofii" (O pisaniu historii filozofii); 2) R. Ingardena: „Dzięki wielorazowej recepcji jednego i tego samego dzieła filozoficznego (względnie [...] poglądu filozoficznego), dzięki istnieniu opracowań, krytyk, dyskusji i historii filozofii pojawia się na terenie tak samej filozofii, jak i literatury filozoficznej jeszcze jeden szczególny proces, mianowicie życie pewnego poglądu względnie dzieła filozoficznego" (O przedmiocie historii filozofii). Komentując wypowiedź Ingardena, Garewicz pisze, że życie poglądu (recepcja) wytwarza zmieniającą się tradycję filozoficzną, czyli wiąże się z „istnieniem i rozwojem filozofii w rozumieniu historycznym". 
dzamy je w filozoficznej przeszłości. Innymi słowy, podejmując problemy w jakiś sposób aktualne wcześniej, wkraczamy de facto na tę samą drogę, którą kiedyś szli inni - i dlatego są oni nam potrzebni. Leo Strauss i Herbert Schnädelbach mówili o niezbywalnej potrzebie kontaktu z filozoficznymi poprzednikami, „by mogli nas krytykować, a my byśmy mogli się od nich uczyć"4. Szymon Wróbel natomiast w opublikowanym niedawno manifeście historiografii retroaktywnej liczył w ten sposób na inspirujący „intelektualny pożar”, „kulturowe przesilenie” lub „afektywną traumę"s. Niezwykle radykalnie wypowiadał się na ten temat Leszek Kołakowski, gdy pisał w Horrorze metafizycznym, że „od wieków filozofia utwierdzała swą prawomocność stawiając i odpowiadając na pytania odziedziczone po sokratejskiej i przed-sokratejkkiej tradycji”, a filozof niezdolny do utożsamienia się z Sokratesem (nawet choćby miał odrzucić całkowicie jego poglądy) nie należy do tej cywilizacji ${ }^{6}$. Wpisanie się zatem w określoną tradycję (cokolwiek miałoby to znaczyć) stanowi integralny element tożsamości filozofa i sposób jej budowania. Inaczej, element samowiedzy - chodzi o pamięć o przeszłości nie jako zbiorze osobliwości lub bajce opowiedzianej przez szaleńca ${ }^{7}$, lecz jako ciągłym, systematycznym wysiłku poznawczym. Dziś jest to problem szczególnie ważny, gdyż - mówiąc językiem Skargi - żyjemy w samym środku przemian formacyjnych, a w wielu przypadkach towarzyszy filozofom poczucie zerwania, jakiejś demarkacyjnej cezury, która skutecznie odgradza od przeszłości.

Jeżeli zatem studium recepcji - jak pokazują konkretne przykłady - jest w stanie ukazać dzieje filozofii inaczej, niż jesteśmy do tego przyzwyczajeni przez dominujące dziś trendy badań historycznych, to można domniemywać, że także w kwestii ciągłości doświadczenia filozoficznego badania recepcji mogą naświetlić przeszłość filozofii odmiennie, dając obraz uzupełniający, a być może i rewidujący ujęcia tradycyjne.

Historiografię filozofii uprawia się na ogół bezrefleksyjnie - jakby dla niej samej, nieraz na zasadzie gromadzenia muzealnych eksponatów. Aktywne wiązanie badań historycznych z filozofowaniem w duchu otwartej formuły historia philosophiae ancilla philosophiae stanowi raczej zapoznaną możliwość. Nie kwestionując dokonań historiografii „czystej”, iść można jednak w innym kierunku. Pokazał to Wróbel, postulując i realizując w praktyce historiografię jako filozoficzną anamnezę opartą na retroaktywnej lekturze, której celem jest ustanowienie własnej genealogii filozoficznej. Chodzi o historiografię stwarzającą - to „jedyny cel pisarstwa historycznego”, powiada (!) - „własną serię rodowodową”. Oczywiście można w dowolnej konwencji fascynować się myślą przeszłości - wspófilozofować z Platonem, Arystotelesem, Kantem, Heglem, Husserlem - ale o tym, czy jest to "gra szklanych paciorków” przysparzająca intelektualnej satysfakcji, czy też „gra prawdy”, w ramach której człowiek buduje autentyczną wiedzę o sobie i o świecie takim, jakim jest hic et nunc, rozstrzyga moment utożsamienia. Wydaje się, że ostatnia książka Wróbla Filozof i terytorium otwarta jest na tę drugą możliwość w ramach rozstrzygającego momentu identyfikacji autora z jej

\footnotetext{
4 H. Schnädelbach, Morbus hermeneuticus, [w:] idem, Rozum i historia, Warszawa 2001, s. 226; R. Mordarski, Leo Strauss a problem teologiczno-polityczny, [w:] L. Strauss, Jerozolima i Ateny oraz inne eseje z filozofii politycznej, tłum. R. Mordarski, Kęty 2012, s. 10.

5 S. Wróbel, Lektury retroaktywne. Rodowody współczesnej myśli filozoficznej, Kraków 2014, s. 16; idem, Co to jest historia filozofii?, „Przegląd Polityczny” 2015, nr 130, s. 158-170.

6 L. Kołakowski, Horror metaphisicus, Warszawa 1990, s. 7.

7 L. Strauss, Prawo naturalne w świetle historii, Warszawa 1969, s. 23.

8 S. Wróbel, Co to jest historia filozofii?, s. 170.
} 
bohaterami: Baczką, Kołakowskim, Pomianem i Siemkiem, w dążeniu do włączenia się w „sztafetę pokoleń, sztafetę dziedziczenia myśli i postaw”.

I tu paralela. Otóż Hans Robert Jauss w artykule Historia literatury jako prowokacja dla nauki o literaturze widział w badaniu recepcji na gruncie historii literatury szansę ujęcia jej dziejów jako jedności - szansę, której nie wykorzystywały, jego zdaniem, dominujące w latach sześćdziesiątych szkoły: formalistyczna i marksistowska. Jauss stwierdzał zapoznanie autentycznej historyczności literatury, którą, jego zdaniem, odnaleźć może badanie recepcji i oddziaływania dzieł. Historyczność dzieła sztuki - pisał - „nie sprowadza się do jego funkcji przedstawiającej albo ekspresywnej, ale polega zarazem koniecznie na jego oddziaływaniu" ${ }^{10}$. Autentyczna historyczność literatury polega w związku z tym na doświadczaniu dzieł literackich przez czytelników, a w historii literatury chodzić powinno o to, by pokazać na podstawie historycznego ciągu dzieł i lektur całość literatury jako prehistorię jej współczesnego doświadczenia, by ukazać literaturę jako nieprzerwaną tradycję. Innymi słowy, swoje intuicje i postulaty uzasadniał Jauss przekonaniem, że historyczność literatury nie pokrywa się ani z przemianą systemów estetyczno-formalnych (ujęcia formalistyczne), ani z pragmatyczną historią zmieniających się stosunków społecznych, które znajdują wyraz w literaturze - stosunków, których literatura jest ekspresją lub funkcją (podejście marksistowskie). Ponadto - twierdził Jauss w zgodzie z polskimi teoretykami recepcji - rola odbioru i odbiorcy tekstu literackiego jest bardziej wielostronna niż rola twórcy tekstu, „albowiem jakość i ranga dzieła literackiego nie wynika ani z biograficznych - czy historycznych okoliczności jego powstania; ani z jego miejsca w ciągu ewolucji gatunkowej, lecz z trudno uchwytnych kryteriów oddziaływania, recepcji i pośmiertnej sławy"11. Stąd estetykę produkcji i przedstawiania właściwą ujęciom tradycyjnym trzeba poszerzyć o estetykę recepcji i oddziaływania. Tylko w ten sposób można rozwiązać problem rozumienia „historycznego ciągu dzieł literackich jako spójnej całości historii literatury” ${ }^{12}$. Czytelnik nie jest zatem stroną pasywną, ale sam jest „historiotwórczą energią”13.

Czy postawienie tak zdefiniowanego problemu recepcji na gruncie badań filozoficznej przeszłości stwarza analogiczne perspektywy? Pytanie to warto rozważyć nie tyle z intencją powtórzenia w kontekście filozoficznym rozumowania Jaussa, ile przechwycenia go na sposób Deborda i transponowania (ze świadomością różnic między literaturą a filozofią) w rzeczywistość badań historycznofilozoficznych po to, by zwrócić uwagę na tkwiące w nich możliwości, ale i trwałe trudności.

Daje się bowiem na pewno zauważyć podobieństwo sytuacji. Po pierwsze, problem historyczności filozofii jest wciąż aktualny, po drugie, kontrowersyjne są rezultaty uzyskane dotychczas w tej materii ${ }^{14}$. Po trzecie, Garewicz, analogicznie jak Jauss, trafnie wskazał na rywalizujące ze sobą na gruncie historiografii filozofii dwa generalne podejścia: teoretycz-

\footnotetext{
9 Idem, Filozof i terytorium. Polityka idei w myśli Leszka Kołakowskiego, Bronisława Baczki, Krzysztofa Pomiana i Marka J. Siemka, Warszawa 2016, s. 23-24.

10 H. R. Jauss, Historia literatury jako prowokacja dla nauki o literaturze, tłum. M. Łukasiewicz, Warszawa 1999, s. 138. „Inaczej mówiąc: literatura i sztuka - pisze Jauss - stają się procesualną historią dopiero wtedy, gdy następstwo dzieł zapośredniczone jest nie tylko przez podmiot produkujący, ale także przez podmiot konsumujący - przez interakcję autora i publiczności" (ibidem).

11 Ibidem, s. 128.

12 Ibidem, s. 142.

13 Ibidem.

14 Zob. Z Czernecki, Problem historycznej ciągłości filozofii w historiografii współczesnej, „Studia Filozoficzne” 1973, nr 9, s. 71-91.
} 
no-problemowe (zakresowe) i kulturalistyczne (genetyczno-funkcjonalne), które proponują rozwiązania niedające się ze sobą uzgodnić; Skarga pisała onegdaj o stałym napięciu między historia prawdy i historia prawdziwa ${ }^{15}$. Otóż nieufność budzą zarówno ujęcia nadmiernie konstrukcyjne (nieraz przy tym teleologiczne), a ku nim ciąży w wielu przypadkach historiografia problemowo-teoretyczna, jak i nadmiernie atomizujące dzieje filozofii podejścia kulturalistyczne (redukcjonistyczne) - wyjaśniające dzieje filozofii przez niepowtarzalny kontekst kulturowy i społeczny. Garewicz - przypomnijmy - stwierdzał, że dotychczas nie udało się tych przeciwstawnych stanowisk pogodzić, ale postulując opracowanie teorii recepcji, spodziewał się przezwyciężyć ich antynomię, co zbliża jego postulaty do ujętych systematycznie dążeń Jaussa ${ }^{16}$.

Przyjrzyjmy się przede wszystkim dotychczasowym doświadczeniom i ustaleniom polskich badaczy recepcji, którzy dostrzegali w taki czy inny sposób problem tradycji - ciągłości doświadczenia filozoficznego. Chodzi nie o panoramę stanowisk, ale o selektywne wskazanie koncepcji, które naprowadzają na badanie recepcji w rozważanym kierunku.

I tak Andrzej Walicki - kontynuując pracę podjętą przez Stefana Harasska, pioniera badań recepcji idei filozoficznych $\mathrm{w}$ Polsce ${ }^{17}$ - stwierdzał w artykule Polska recepcja myśli Kanta $w$ okresie międzypowstaniowym, że dzieje recepcji bywają interesujące w dwojakim sensie: primo, z teoretycznego, ściśle filozoficznego punktu widzenia - gdy recepcja przybiera formę szkoły filozoficznej, która stawia sobie za cel „studiowanie i rozwijanie w określonym kierunków poglądów Mistrza”; secundo, z punktu widzenia światopoglądowego, kulturalistycznego - „z punktu widzenia dziejów prądów umysłowych i kultury filozoficznej jakiegoś kraju w określonej epoce historycznej” ${ }^{18}$. W ustaleniach Walickiego warte wyeksponowania jest to, że w modelowaniu badań recepcji nie chodzi mu o stworzenie lub uzupełnianie mozaiki poglądów reprezentatywnych dla danej epoki, lecz o uzyskanie wglądu w rzeczywisty proces historyczny.

Jaka jest jednak natura recepcji? Na to pytanie odpowiadał Bronisław Baczko w szkicu Hegel i Rousseau. Zagadnienie recepcji ujął on jako problem „socjologii poznania filozoficznego", a dzieje recepcji jako dzieje dezintegracji recypowanej doktryny. Studium tak ujmowanej recepcji stwarza dwie przede wszystkim możliwości: jest z jednej strony znakomitym sposobem poznania dążeń filozofa oddającego się lekturze dzieł swojego poprzednika, z drugiej - sposobem ukazania potencjału filozofii recypowanej. Recepcja wszakże to przede wszystkim transformacja. Generalnie wszelka interpretacja, powiada Baczko, nawet jeśli towarzyszy jej złudne przeświadczenie o kontynuacji cudzej myśli, jest zawsze wykroczeniem poza pierwotną całość ${ }^{19}$. Ten ostatni czynnik, najbardziej jak się zdaje dynamizujący recepcję, wyjaśniał Baczko, przenosząc na pisarstwo filozoficzne zjawisko dostrzeżone przez Ingardena w strukturze dzieła literackiego: „każdy system filozoficzny - pisał - posiada swoje miejsca niedookreślone" - wieloznaczności, luki problemowe, niedopowiedzenia a dookreślanie systemu jest procesem historycznym, uwarunkowanym w dużej mierze przez

\footnotetext{
15 B. Skarga, Złudzenia i nadzieje historyka filozofii, [w:] eadem, Przeszłość i interpretacje. Z warsztatu historyka filozofii, Warszawa 1987, s. 42-60.

16 J. Garewicz, Kilka uwag..., s. 106-107.

17 W pracy Kant w Polsce przed rokiem 1830 (Kraków 1916) Harassek postanowił „badać stosunek naszej umysłowości do Kanta oraz śledzić wpływ, jaki filozof ten mógł wywrzeć na sposób myślenia w Polsce" (s. 1).

18 A. Walicki, Polska recepcja myśli Kanta w okresie międzypowstaniowym, [w:] Dziedzictwo Kanta, red. J. Garewicz, Warszawa 1976, s. 139.

19 B. Baczko, Lewica i prawica heglowska, [w:] idem, Człowiek i światopoglądy, Warszawa 1965, s. 216.
} 
czynniki pozateoretyczne lub pozasystemowe. Otóż to dookreślanie skutkuje „dezintegracją" doktryny - dezintegracją, która generuje nowe zjawiska intelektualne ${ }^{20}$.

Baczko powrócił do tematu recepcji w szkicu Lewica i prawica heglowska w Polsce. Jak później Jauss, twierdził tu, że każda recepcja doktryny filozoficznej jest aktem selekcji: społecznego, moralnego, intelektualnego wyboru. Stąd w transformacji sensu idei stroną czynną jest nie tyle doktryna, ale ci, którzy „ową doktrynę przejmują"21.

To przejmowanie jest nieraz aktem filozoficznej ekspresji lub autokreacji. Zwrócił na to uwagę Krzysztof Pomian, komentując książkę Baczki Rousseau: samotność i wspólnota. Zauważył mianowicie, że jest ona formą filozoficznego samookreślenie autora. Twierdził, że w studiach nad myślą Rousseau program badań recepcji stał się dla Baczki okazją do zbudowania własnego stanowiska filozoficznego. Baczko sam, jego zdaniem, wpisywał się w nurt recepcji Rousseau i zgodnie z tezą, że recepcja jest formą dookreślenia miejsc otwartych w filozofii recypowanej, podjął problem, „który jest równie aktualny dziś - co przed dwustu laty" - chodziło o problem alienacji struktur i instytucji społecznych oraz związany z tym proces depersonalizacji i urzeczowienia jednostki, który rzutuje na jej światopogląd $\mathrm{d}^{22}$.

Tezę Baczki, że recepcja jest zawsze deformacją, potwierdziła praca SkargiOrtodoksja i rewizja w pozytywizmie francuskim. Autorka rewidowała w niej stereotypowe wyobrażenia na temat pozytywizmu francuskiego, które proponowała tradycyjna historiografia, stawiając i uzasadniając tezę, że ortodoksyjni comtyści, choć nieraz starali się dochować wierności doktrynie mistrza, nieustannie poza nią wykraczali. Nie ma zatem recepcji bez rewizji. W efekcie, pod wpływem nowych problemów i tendencji, nieustannie dokonuje się transformacja systemu wyjściowego. Na terenie filozofii zatem pojęcie ortodoksji jest kwalifikacją umowną. Wieloletnie badania Skargi nad pozytywizmem polskim i francuskim, nad Bergsonem i tak zwanym przełomem antypozytywistycznym, dotyczyły zjawiska recepcji, które w pewnym momencie zostało zdefiniowane jako przekształcanie się tak zwanych formacji intelektualnych. Od strony stricte teoretycznej i filozoficznej zarazem zwieńczyły je Granice historyczności - inspirowane poststrukturalizmem francuskim studia, w ramach których problematyka recepcji pojawiła się wyraźnie - przypomnijmy - w kontekście takich elementów formacyjnych jak problemy i kategorie.

W sposób, który może wydawać się zaskakujący, z badaniami Baczkii ${ }^{23}$ oraz Skargi korespondują ustalenia Stefana Swieżawskiego. Dwa teksty zwracają tu na siebie uwagę: Studium św. Tomasza u dominikanów w wieku XV oraz Z problematyki metodologicznej badań filozofii $X V$ wieku. Można je ze sobą zestawić, widząc w pierwszym wycinek programowych badań historyczno-filozoficznych ${ }^{24}$, w drugim ich bezpośrednie zaplecze teoretyczne. Studium... to rozprawa na temat recepcji dzieł Tomasza w środowisku zakonu kaznodziejskiego

\footnotetext{
20 Idem, Hegel a Rousseau, [w:] idem, Człowiek i światopoglądy, Warszawa 1965, s. 102-106. „Drugie życie systemu" jest uwarunkowane grą trzech czynników: po pierwsze, ekspresją niepowtarzalnej osobowości, której nie da się imitować; po drugie, krótkotrwałością momentu historycznego, w którym doktryna powstaje i na który jest reakcją; po trzecie, otwartością dzieła, obecnością w nim "miejsc niedookreślonych".

21 Idem, Lewica i prawica heglowska, [w:] idem, Człowiek i światopoglądy, Warszawa 1965, s. 215-216.

22 K. Pomian, Baczko: badanie historyczne i filozofia, [w:] idem, Filozofowie w świecie polityki. Eseje filozoficzne 1957-1974, Toruń 2004, s. 169-173.

23 Obok Baczki, jako badacza i teoretyka recepcji trzeba wymienić z pewnością Leszka Kołakowskiego - zob. Zakończenie. Proces spadkowy o Spinozę książki Kołakowskiego pt. Jednostka i nieskończoność. Wolność i antynomie wolności w filozofii Spinozy, Warszawa 1958, s. 588-625.

${ }^{24}$ Chodzi o obszerny program badań dziejów filozofii w XV wieku, których zwieńczeniem była sześciotomowa monografia Swieżawskiego: Dzieje filozofii europejskiej wXV wieku ukazująca się w latach 1974-1983.
} 
w XV wieku - rozprawa rozumiana jako opracowanie przełomowego fragmentu dziejów tomizmu i reperkusji idei filozoficznych poza filozofią ${ }^{25}$, ale zarazem tekst, który współtworzy rewizję stereotypowego i jednocześnie zdeformowanego wyobrażenia filozofii XV wieku, który stworzyły „najlepiej [...] opracowane historie europejskiej myśli filozoficznej”, zwracające niemal wyłącznie uwagę „na twórczość filozoficzną w stylu humanistycznym”, choć faktycznie filozoficzny klimat epoki kształtowała zarówno tradycja humanistyczna, jak i scholastyczna ${ }^{26}$. Zaskakuje zbieżność wniosków Skargi i Swieżawskiego. W swoich badaniach dziejów filozofii w XV wieku autor Zagadnienia historii filozofii doszedł do przekonania, że operowanie pojęciami ogólnymi, bez których notabene historyk filozofii nie może się obyć (takimi jak: arystotelizm, neoplatonizm średniowieczny, scholastyka, humanizm, renesans i tak dalej), skutkuje nieraz (i jest to niebezpieczny błąd) ich hipostazowaniem: nadawaniem realnego bytu temu, co jest tylko narzędziem badacza, dogodną konstrukcją pojęciową, pozwalającą zapanować nad materiałem ${ }^{27}$. Otóż hipostazowanie takich pojęć jak na przykład: średniowiecze i renesans, scholastyka i humanizm, skojarzone z ich antytetycznym wartościowaniem zaciemnia i deformuje obraz filozofii XV wieku, czyniąc złudzenie zerwania lub braku ciągłości. Swieżawski twierdził (i jest to zbieżne z orientacją badań Skargi), że funkcjonowanie takich stereotypów zrewidować może badanie dziejów problemów filozoficznych w okresach przejściowych. Pokazuje ono wyraźnie, że wiek XV to okres przenikania się „przeciwieństw”, że nie ma zerwania, ale dokonuje się przejście - transitus.

Skarga dochodziła do podobnych konkluzji w artykule O takzwanym „przełomie antypozytywistycznym", stanowiącym pokłosie badań realizowanych w formule analizy przeksztalcania się pozytywistycznej formacji intelektualnej w formację współczesną. Analogicznie jak Swieżawski, rewidowała w nim stereotypy interpretacyjne dotyczące tytułowego zjawiska - mit radykalnego cięcia oraz mit symetrii ${ }^{28}$. Okazuje się, że przejściowość, brak epistemologicznych cięć, pokonywanie epistemologicznych progów, transitus - wszystko to cechy każdej epoki. Otóż prace, których przedmiot w dużej mierze stanowi zjawisko recepcji, takie jak Skargi: Ortodoksja i rewizja w pozytywizmie francuskim lub Kłopoty intelektu. Między Comte'em a Bergsonem, czy Swieżawskiego: Dzieje filozofii europejskiej w XV wieku zdają się uświadamiać czytelnikowi - na konkretnym materiale empirycznym, w sposób wolny od spekulacji i podejmowanego z rozmysłem konstruowania obrazu dziejów filozofii - realną ciągłość doświadczenia filozoficznego.

Wszelako doświadczenia Stanisława Borzyma wyniesione z badań dziejów recepcji bergsonizmu w Polsce osłabiają w dużej mierze nadzieję na uzyskanie, na podstawie studium recepcji, wglądu w jedność filozofii w Gilsonowskim sensie. Sprzyjają też lepszemu zrozumieniu skomplikowanej sytuacji, w której nieuchronnie znajduje się każdy pytający o obecność i trwałość filozoficznej tradycji.

Mianowicie jeśli studium recepcji samo ma zachować strukturalną tożsamość i nie roztopić się w dziejach filozofii ujmowanych z punktu widzenia oddziaływania wielkich filozofów (obraz recepcji kantyzmu niewiele różni się przecież od obrazu dziejów filozofii

25 S. Swieżawski, Studium św. Tomasza u dominikanów w wieku XV, „Roczniki Filozoficzne” 1969, t. XVII, z. 1, s. $19-40$.

${ }^{26}$ Idem, Z problematyki metodologicznej badań filozofii wXV wieku, „Roczniki Filozoficzne” 1965, t. XIII, z. 1, s. 46.

27 Ibidem, s. 44-45.

28 B. Skarga, O tak zwanym „przełomie antypozytywistycznym”, [w:] eadem, Przeszłości i interpretacje..., s. 294-295 . 
po Kancie), to powinno być, jego zdaniem, realizowane w ramach świadomie wyznaczanych wykrojów czasowych i przestrzennych. Trzeba zadowolić się obrazem wyłaniającym się z analizy poszczególnych przypadków. Uzyskujemy wówczas „całościowe spojrzenie na pewne środowisko, na pewien okres - w ramach jakiegoś kręgu kulturowego"29.

To minimalistyczne podejście stanowi z pewnością przeciwieństwo imponujących badań, które prowadził w latach siedemdziesiątych XX wieku Marek Siemek, re-konstruujący genealogię i historię idei transcendentalizmu jako stanowiska epistemologicznego. Zwłaszcza jego obraz dziejów transcendentalizmu - filozofii pokantowskiej - może stanowić dobry przykład, jak doświadczać jedności i długiego trwania myśli filozoficznej, wykorzystując przy tym okazję do filozoficznego samookreślenia ${ }^{30}$. Przykład ten pokazuje jednak, że postulat, aby badanie recepcji ukazywało realne, a nie wyidealizowane, względnie skonstruowane życie koncepcji w dziejach, nie jest łatwy, jeśli w ogóle możliwy do zrealizowania. Każde na przykład odnoszenie przejawów recepcji do tekstów Kanta zapośredniczone jest $\mathrm{z}$ konieczności przez samo rozumienie kantyzmu, które trzeba ujawnić3 ${ }^{31}$. Czyniąc tak, badacz nie umieszcza się jednak w obiektywizującej perspektywie na zewnątrz procesu recepcji, lecz zmuszony jest odnaleźć się sam w historycznym ciągu czytelników królewieckiego filozofa. Nie dysponuje bowiem „uprzywilejowanym” rozumieniem kantyzmu a priori, lecz skazany jest na to, by wydobyć je dopiero z niedookreślonych źródeł. Bez względu zatem na intencje i przeświadczenia - szukając na przykład ostatecznej/właściwej wykładni danej myśli, czy jak Siemek, wyznaczając „główne kierunki właściwej interpretacji Fichtego i Kanta"32 - wpisuje się w proces wypełniania miejsc niedookreślonych tekstów, które bada. Dookreślanie zaś jakiegoś kompleksu myśli, przypomnijmy Baczkę, jest procesem historycznie uwarunkowanym i oznacza, w mniejszym lub większym stopniu nie lustrzane odtworzenie, tylko wyjście poza recypowaną całośćc ${ }^{33}$. Dotykamy tu czegoś na kształt antynomii poznania historycznego, na którą onegdaj zwrócił uwagę Leszek Kołakowski, badając dzieje recepcji spinozyzmu ${ }^{34}$, a którą na użytek prezentowanych rozważań można by ująć następująco: nie ma oczekiwanego sensu recypowany fakt historyczno-filozoficzny bez umieszczenia go w określonej strukturze myśli (bergsonizmu, spinozyzmu, kantyzmu, transcendentalizmu, humanizmu renesansowego, scholastyki i tak dalej). Nie dysponujemy jednak taką strukturą a priori, bez wcześniej ujętych faktów, bo tylko na ich podstawie możemy ją skonstruować; oba zatem elementy - fakt i struktura interpretacyjna - wzajemnie się wyprzedzają. Struktura ta nie może być także uzasadniona przez prowadzone badanie, nie może kształtować się razem z badaniem, gdyż sama musi wyznaczać mu kierunek. Dla Kołakowskiego antynomia ta uzasadniała tezę relatywizmu historycznego - przekonanie o niemożności osiągnięcia w pracy historyka zupełniej obiektywności.

Przypadek, kiedy badacz rości sobie prawo do zrozumienia myśliciela lepiej, niż on sam siebie rozumiał, nie jest skrajny ani też teoretycznie tylko możliwy ${ }^{35}$. Postawę taką zwalczał

\footnotetext{
29 S. Borzym, Bergson..., s. 14.

30 Nie chodzi tu jedynie o Ideę transcendentalizmu u Fichtego i Kanta, Warszawa 1977, ale o obszerny cykl artykułów pisanych przez Siemka w latach siedemdziesiątych, których reprezentatywny wybór został opublikowany pod tytułem Filozofia, dialektyka, rzeczywistość, Warszawa 1982.

31 S. Borzym, Bergson..., s. 19. Autor rozważa tu analogiczną sytuację w przypadku recepcji bergsonizmu.

32 M. Siemek, Idea transcendentalizmu..., s. 10.

33 B. Baczko, Hegel..., s. 103.

34 L. Kołakowski, Jednostka..., s. 608.

35 Zob. idem, Banał Pascala, [w:] B. Pascal, Prowincjałki, tłum. T. Żeleński-Boy, Warszawa 1963, s. 320.
} 
usilnie Leo Strauss, żywiący przekonanie odmienne, że można zrozumieć filozofa z przeszłości - wbrew historycyzmowi - tak jak on sam siebie rozumial, i że jest to prawdziwe historyczne rozumienie umożliwiające autentyczną, dokonującą się we wspólnej przestrzeni, rozmowę z dawnymi mistrzami ${ }^{36}$. Korygująco-normatywne nastawienie przyjął otwarcie Siemek i nieuchronnie spotkał się z zarzutem nadinterpretacji, a nawet nierozumienia istoty transcendentalizmu. Analogiczne wszakże nadinterpretacje przypisują do dziś historycyści Straussowi ${ }^{37}$. Jedność doświadczenia filozoficznego nie jest zatem oczywista i dążenie do niej ma, jak się zdaje, swoją cenę.

Jeśli bowiem zgodzimy się na to, że recepcja jest zawsze dezintegracją (Baczko), a jej badacz sam nieuchronnie włącza się w historyczny ciąg, historycznie uwarunkowanych czytelników dokonujących dookreślania zawsze otwartych kompleksów myśli, to nie sposób uniknąć kłopotliwej konstatacji, że badanie dziejów recepcji jest deformacją deformacji zachodzącą w polu re-konstruowanej doktryny. Ryzyko uzyskiwania w ten sposób obrazów opacznych, filozoficznych karykatur oczywiście istnieje, ale w przekonaniu Kołakowskiego wysiłek konfrontacji różnych punktów widzenia, opierania się stereotypom interpretacyjnym może je znacznie ograniczyć ${ }^{38}$. Borzym był w tym przypadku zdania, że deformujący/dezintegrujący (wyrażeń tych nie należy wartościować ujemnie) charakter recepcji wiąże się z nieuniknioną projekcją, stanowiącą konieczny momentu rozumienia tekstu. Recepcja - pisał - jest sama „rozumieniem” w pewnych określonych uwarunkowaniach podmiotowych ${ }^{39}$. Subiektywizm ten problematyzuje zakres dostępności tego, co recypowane, ale studiując odbiór Bergsona w Polsce, Borzym żywił nadzieję, że projektujące rozumienia tekstu, mimo swoich dowolności, „mogą prowadzić do stopniowej konwergencji tekstu i jego recepcji, Gadamerowskiego stopienia horyzontów - danego przez tekst i wnoszonego przez czytelnika" ${ }^{40}$. Tak rozumiana recepcja ukazuje z pewnością potencjał recypowanej myśli, aktualizowany w procesie kolejnych historycznych przybliżeń, ale dokonuje się przede wszystkim, jak pisał Kołakowski, modo recipientis, jako próba odnalezienia przez teraźniejszość bodźców, „które pozwolą jej odpowiedzieć na jej własne, to znaczy przez jej epokę postawione pytania"41.

Wszystko to skłania, by uznać za Straussem, że przeszłość jest bardziej zagadkowa, niż się na ogół sądzi, oraz prowokuje do stałej czujności wobec pytania: „czy do prawdy historycznej nie jest równie trudno dotrzeć, jak do prawdy filozoficznej?”"42. Bez względu jednak na to, jak odpowiemy na tak postawione pytanie, warto zdawać sobie sprawę z tego, że autentycznym warunkiem rozumienia przeszłości (pewnie nie jedynym) jest szukanie w niej odpowiedzi na problemy ugruntowane w naszej rzeczywistości historycznej; że rozumienie/interpretacja służy ostatecznie poszerzeniu świadomości - samorozumieniu. Tekst z przeszłości może zatem znaleźć się w żywej relacji do czytelnika dzięki wysiłkowi przezwyciężania dystansu, dzięki przyswojeniu i aktualizacji zawartej w nim treści.

\footnotetext{
36 L. Strauss, Filozofia polityczna i historia, [w:] idem, Jerozolima i Ateny..., s. 174; oraz idem, O tyranii, Kraków 2009, s. 24-25.

37 Idem, O zapomnianym sposobie pisania, [w:] idem, Jerozolima i Ateny..., s. 238-248.

38 L. Kołakowski, Jednostka..., s. 606-607.

39 S. Borzym, Bergson..., s. 16-17.

40 Ibidem, s. 17.

41 L. Kołakowski, Jednostka..., s. 612.

42 L. Strauss, O zapomnianym..., s. 248.
} 